\title{
Dolichoderus thoracicus Nest on Seasonal Fruits in the Society Plantations of Sirah Pulau Padang Sub-district
}

\author{
Ari Sugiarto \\ Email: sugiartoari13@gmail.com
}

\begin{abstract}
Dolichoderus thoracicus is an ant species which is common found. The presence of D. thoracicus on a plants can minimize the potential threat from insect, especially fruit destructive insects. The society plantations in Sirah Pulau Padang Sub-district are planted with seasonal plants which certainly have the potential threat from fruit destructive insects. It is necessary to observation of $D$. thoracicus nest on seasonal fruits in society plantations of Sirah Pulau Padang Sub-district to estimate the potential threat from fruit destructive insects. This observation was conduct on January 2019 by observing seasonal fruits found in the society plantations. The results of observation made, found of $D$. thoracicus nest on mangoesteen and rambutan fruit. Also found the $D$. thoracicus coloni on duku and raman fruit. The presence of nest and coloni of $D$. thoracicus on mangoesteen, rambutan, duku, and raman can be estimated the potential threat from fruit destructive insects which less compared to other seasonal fruits in society plantations of Sirah Pulau Padang Sub-district.
\end{abstract}

Keywords: Dolichoderus thoracicus, Seasonal fruits, Sirah Pulau Padang Sub-district, Society plantations

\section{Introduction}

Dolichoderus thoracicus is an ant species which is common found, this is because the $D$. thoracicus is widely spread. According to Wiryadiputra (2007), Anshary and Flora (2008), and Murnawati et al. (2018), D. thoracicus can be a biological control agent which is efficient enough to overcome from pests on plants and predators for Conopomorpha cramerella, Helopeltis spp., and other pests.

The society plantations in Sirah Pulau Padang Sub-district to many planted with seasonal plants namely Durio zibethinus, Lansium domesticum, Garcinia mangostana, Nephelium lappaceum, Baccaurea motleyana, and Bouea macrophylla (Sugiarto, 2019). The presence of $D$. thoracicus on seasonal fruits in the society plantations can be helpful to minimaze the potential threat from fruit destructive insect, therefore it is necessary to observation of $D$. thoracicus nest on seasonal fruits in the society plantations of Sirah Pulau Padang Sub-district. The result of this observation can be helpful to

estimated the potential threat from fruit destructive pests to seasonal fruit in the society plantations.

\section{Research Methods}

This observation was conducted on January 2019, located in Sirah Pulau Padang Sub-district, Ogan Komering Ilir District, South Sumatra. The Observation conducted by observed of seasonal fruits which found in the society plantations is found the nest and colony of $D$. thoracicus. Other than that, also observed parts of the fruit which found the nest and colony of D. thoracicus. According to Sugiarto (2018), harvest season in the society plantations of Sirah Pulau Padang Subdistrict starting from October until March. The date of observation result are presented in the form of descriptive paragraphs.

\section{Results and Discussion}

Based on the results of observation was conducted in society plantations of Sirah Pulau Padang Sub-district, found the 
D. thoracicus nest on mangoesteen (Garcinia mangostana) and rambutan fruit (Nephelium lappaceum). Found too the D. thoracicus colony on duku (Lansium domesticum) and raman fruit (Bouea macrophylla). Not found the nest and colony of D. thoracicus on durian (Durio zibethinus) dan rambai fruit (Baccaurea motleyana).

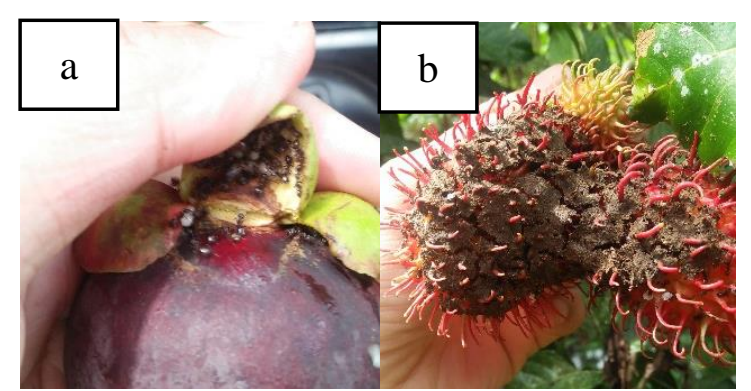

Figure 1. Dolichoderus thoracicus nest on fruit a. mangoesteen, b. rambutan.

D. thoracicus nest which found on mangoesteen fruit (Figure 1) are below the fruit petals. while on rambutan fruit (Figure 1) are found on the surface of the outer skin with many hairs. There are quite striking differences $D$. thoracicus nest on mangosteen and rambutan. D. thoracicus nests in mangosteen fruit have little material used to make nests, while the material used to make nests on rambutan fruit is more. $D$. thoracicus nest material on mangosteen fruit while on slightly estimated is only used to attach the petals to the skin of the fruit, while the nest material with more fruit is estimated because on rambutan fruit does not have fruit petals so D. thoracicus requires more material to make nests. $D$. thoracicus nest material on rambutan fruit is attached to the hairs found on the skin of the fruit, so there is space which can be occupied by D. thoracicus. According to Anshary and Flora (2008), D. Thoracicus tends to be attracted to a dark place.

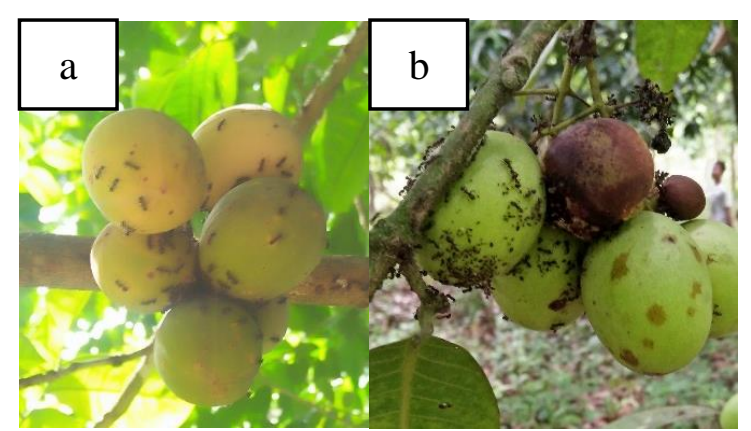

Figure 2. Dolichoderus thoracicus colony on fruit a. duku, b. raman

D. thoracicus colony which found on duku and raman fruit (Figure 2) are in the space between the fruit and the fruit stalk. According to Anshary and Flora (2008), the behavior of $D$. thoracicus which tends to live colonizes because $D$. thoracicus tends to live clustered in a dark place or low light intensity. According to Attygalle (1998), D. thoracicus communicates with pheromones produced by the pavan glands.

D. thoracicus nest or colonies are not found thoroughly on each mangosteen, rambutan, duku, and raman fruit. D. thoracicus nest tend to be easier to find on mangosteen fruit compared to rambutan fruit. D. thoracicus nest on rambutan fruit are more likely to be found on rambutan fruits which are in the shade and on rambutan fruit varieties which has long hair and large fruit sizes. D. thoracicus colony on duku and raman fruit tend to be found on fruits that are under shade and the number of fruits is large in one stalk.

Multiply the $D$. thoracicus colony in plants can be done by making artificial nests, namely wiht using bamboo, coconut leaves, and brown sugar as a source of food (Murnawati, 2018). Besides brown sugar, Dolichoderus sp. also interested in coconut oil (Sugiarto, 2018). The presence of $D$. thoracicus on a plant can help overcome plant pests, especially in fruit (Murnawati, 2018), namely by covering the surface of the fruit (Wiryadiputra, 2007).

\section{Conclusion}

The presence of nest and colony of D. thoracicus on mangosteen, rambutan, 
duku, and raman fruit can be estimated the potential threat from fruit destructive insects which smaller compared to durian and rambai fruit in society plantations in Sirah Pulau Padang Sub-district.

\section{References}

Anshary, A and Flora, P. 2008. Teknik Perbanyakan Dan Aplikasi Predator Dolichoderus thoracicus (Smith) (Hymenoptera: Formicidae) Untuk Pengendalian Penggerek Buah Kakao Conopomorpha cramerella (Snellen) Di Perkebunan Rakyat. J. Agroland. 15(4): 278-287.

Attygalle, A.B. 1998. Trail Pheromone from the Pavan Gland of the Ant Dolichoderus thoracicus (Smith). Naturwissenschaften. 85(1): 275277.

Murnawati., Annawaty., and Umrah. 2018. Monitoring Ketahanan Hidup Semut Hitam Dolichoderus thoracicus Smith Pada Sarang
Buatan Di Tanaman Kakao Biocelebes. 12(2):62-68.

Sugiarto, A. 2018. Utilization of Coconut Oil (Cocos nucifera L.) for Provoke The Presence of Ants (Hymenoptera: Formicidae). (Online). https://doi.org/10.31220/osf.io/45 gtj. Accessed on January 29, 2019.

Sugiarto, A. 2019. Ecotourism Development Potential in Sirah Pulau Padang Sub-district Reviewed from the Society Plantation Sector. (Online). https://doi.org/10.31220/osf.io/xk $48 \mathrm{v}$. Accessed on January 29, 2019.

Wiryadiputra, S. 2007. Pemapanan Semut Hitam (Dolichoderus thoracicus) Pada Perkebunan Kakao dan Pengaruhnya Terhadap Serangan Hama Helopeltis spp. Pelita Perkebunan. 23(1), 57-71. 